\title{
crianças inventando mundos e a si mesmas: ideias para pensar a autoria narrativa infantil
}

\author{
gilka girardello ${ }^{1}$ \\ universidade federal de santa catarina - brasil
}

resumo

O artigo discute a importância e as possibilidades de valorização da autoria narrativa infantil no cenário contemporâneo, considerando o papel que nela desempenham a imaginação e as experiências vividas pelas crianças. Entre os pressupostos do trabalho está a potência geradora que a narrativa exerce sobre o imaginário, retomada aqui a partir de Paul Ricoeur, Richard Kearney e Maxine Greene. A discussão, de caráter ensaístico, leva em conta a crítica à noção de autoria como fundação ou propriedade, mas concentrase na dimensão ético-poética da autoria, entendida como um fazer discursivo no qual as crianças explorem a linguagem mais precisa e singular para a invenção de histórias e ao mesmo tempo para sua própria construção como sujeitos. Reflete-se também sobre algumas propostas de criação narrativa com crianças, a partir de uma concepção lúdica e dialógica de autoria, na qual entram em livre jogo a imaginação individual, a memória e a apropriação cultural, a abertura à historicidade e o compartilhamento social. Por fim, a discussão sobre autoria narrativa infantil é ampliada por lembranças de infância de escritores, sobre o que os animou a criar histórias quando crianças, destacando-se a necessidade de um tempo, de um espaço, da escuta do outro e de textos culturais inspiradores para uma criação de histórias que possa significar para as crianças a experiência de uma grande aventura interior.

palavras-chave: autoria; narrativa; imaginação; crianças

\section{children inventing worlds and themselves: considering children's authorship of narratives}

This essay discusses the importance of and opportunities for giving value to children's authorship of narratives, considering the role that their imagination and experiences perform in them. The work assumes that narratives have great potential to stimulate the imaginary as it is conceived by Paul Ricoeur, Richard Kearney and Maxine Greene. The discussion considers criticism of the notion of authorship as a foundation or property, and concentrates on the ethical-poetic dimension of authorship, understood as a discursive production in which children explore a highly precise and unique language to invent stories and simultaneously construct themselves as subjects. The article also reflects on some further proposals for creating narratives with children, based on a ludic and dialogical concept of authorship, in which enter into a free interplay individual imagination, memory and cultural appropriation, an opening to historicity and social sharing. Finally the discussion about children's narrative authorship is expanded by considering the childhood memories of writers and what inspired them to create stories as children. This highlights the need to provide a time and space to listen to others as well as cultural texts that can inspire the creation of stories that can provide to the children the experience of a great interior adventure.

keywords: authorship; narrative; imagination; children

\footnotetext{
11 E-mail: gilka@floripa.com.br
} 


\section{niños inventando mundos y a sí mismos: ideas para pensar la autoría narrativa infantil}

resumen

El artículo, de carácter ensayístico, discute la importancia y las posibilidades de valoración de la autoría narrativa infantil en el escenario contemporáneo, considerando el rol que en ella desempeñan la imaginación y las experiencias vividas por los niños. Entre los presupuestos del trabajo se encuentra la potencia generadora que la narrativa ejerce sobre el imaginario, retomada acá a partir de Paul Ricoeur, Richard Kearney y Maxine Greene. La discusión toma en consideración la crítica a la noción de autoría como fundación o propiedad, pero se concentra en la dimensión ético-poética de la autoría, entendida como un quehacer discursivo en el cual los niños exploran el lenguaje más preciso y singular para la invención de historias y al mismo tiempo para su propia construcción como sujetos. También se reflexiona sobre algunas propuestas de creación narrativa con niños, a partir de una concepción lúdica y dialógica de autoría, en la cual entran en libre juego la imaginación individual, la memoria y la apropiación cultural, la apertura a la historicidad y el intercambio social. Finalmente, la discusión sobre autoría narrativa infantil se amplía con recuerdos de infancia de escritores, sobre lo que los estimuló a crear historias cuando eran niños, subrayando la necesidad de un tiempo, un espacio, el escuchar al otro y los textos culturales inspiradores en la creación de historias que pueda significar para los niños la experiencia de una gran aventura interior.

palabras clave: autoría; narrativa; imaginación; niños. 
crianças inventando mundos e a si mesmas:

ideias para pensar a autoria narrativa infantil

\begin{abstract}
"Se a voz de uma mulher contando histórias tem o poder de trazer crianças ao mundo, é também verdade que uma criança tem o poder de trazer histórias à vida". A frase do romancista Paul Auster é inspirada pela mítica Scherazade, que, ao longo de mil e uma noites desfiando narrativas para o sultão, gerou três filhos dele e acabou amolecendo o coração de pedra do monarca. Auster comenta que "a necessidade que as crianças têm de histórias é tão fundamental como sua necessidade de comida, e se manifesta como se fosse uma fome. Me conte uma história, diz a criança. Me conte uma história. Me conte uma história, papai, por favor!"2 (AUSTER, 1982. p.154).
\end{abstract}

A necessidade imperiosa de ouvir histórias que a criança sente é bem conhecida e estudada. Inúmeros autores, em diferentes campos, reiteram o papel da recepção narrativa para que as crianças descubram quem são, conheçam as cores, luzes e sombras do mundo de forma segura, ampliem seus horizontes imaginários e deem mais significado às suas vidas. Neste trabalho, o foco recai sobre o papel das crianças na invenção e na narração de histórias. Para as crianças, não só o ouvir, mas também o contar histórias pode ser uma espécie de fome.

Por que é importante que as crianças enriqueçam ao máximo o seu poder de inventar e contar histórias? Elas, que são recém-chegadas ao mundo, o que teriam afinal de tão precioso para contar? Afinal, não é a memória de quem muito viu e viveu a grande fonte da vitalidade narrativa? Supomos que para quem se dispõe a ler um artigo com este tema, tais questões nem tenham razão de ser. Afinal, entre os estudiosos da infância contemporânea já estão bem estabelecidas as noções de que a palavra da criança tem valor, que as crianças são seres do presente e não ensaios de futuro, possuindo também um passado que transparece em suas lembranças e que, aliado à imaginação, fornece o sabor e a substância de suas narrativas. O que faremos aqui então é explorar com mais detalhes alguns aspectos que entram em jogo na criação narrativa das crianças, e principalmente a ideia de autoria narrativa infantil, apoiada em uma rede teórica em que se entrelaçam imaginação, experiência e memória. ${ }^{3}$

Se, com Hannah Arendt (2003), acreditamos na potência da novidade que as crianças possam trazer ao mundo, é também Arendt que não nos deixa

\footnotetext{
2 Tradução da autora, bem como as das demais citações de textos que constam em inglês nas referências.

${ }^{3}$ Entre as pesquisadoras que hoje no Brasil trabalham nesta mesma direção, citamos Hartmann (2015), Fernandes (2009) e Campos (2016). Os diálogos com elas, para nós muito preciosos, estão presentes nas entrelinhas deste artigo.
} 
esquecer a responsabilidade específica que nos cabe, enquanto adultos, para que isso possa acontecer. O cuidado com a imaginação infantil emerge como uma tarefa primordial nessa pauta. Italo Calvino foi dos que melhor formulou a apreensão contemporânea quanto ao futuro da imaginação, quando advertiu que, no atual "dilúvio de imagens pré-fabricadas", estaríamos correndo o risco de perder a fundamental capacidade humana de "pôr em foco visões de olhos fechados", de "pensar por imagens" (CALVINO, 1990, p.107-108). Esse temor tem reverberado em discussões mais recentes na educação, principalmente aquelas mais sensíveis ao que acontece com as crianças. Dele se decanta como indiscutível a ideia de que a imaginação é um valor a ser preservado. A possibilidade de conceber o que ainda não existe - inventando projetos e histórias alternativas ao que conhecemos e ao mesmo tempo desmanchando miragens - é uma questão crucial. Ela requer a capacidade de ver através do presente mais do que é dado à percepção, num processo do qual uma grande aliada é a liberdade da arte.

Entre os pensadores contemporâneos da educação, destaca-se a reflexão de Maxine Greene (1995), pela ênfase que atribui à imaginação no cuidado com o mundo e na responsabilidade pela transformação social. Para ela, o papel da imaginação, da literatura e da arte não é o de resolver problemas, nem o de apontar caminhos, nem tampouco o de empreender; seu papel é o de ajudar a vislumbrar aquilo que o hábito nos acostumou "a não ver, a não ouvir, a não esperar" (GREENE, 1995, p.28):

É a imaginação, com sua capacidade de dar ordem ao caos e de abrir a
experiência ao misterioso e ao estranho, o que nos impele a jornadas
rumo a lugares onde nunca estivemos antes [...] Talvez seja a capacidade
imaginativa o que nos permite experimentar com empatia diferentes
pontos de vista e até mesmo interesses contrários aos nossos. A
imaginação pode ser um modo de sairmos de nosso próprio centro, de
rompermos os confins do privatismo, em direção a um espaço onde seja
possível ficar face a face com os outros e dizer em voz alta: 'Aqui
estamos'." (GREENE, 1995, p.23-31)

Em pesquisas anteriores, procuramos saber quais seriam os aspectos favoráveis à imaginação infantil na visão de um grande número de estudiosos: pedagogos, filósofos, psicólogos, linguistas e teóricos da literatura e da arte. Em muitas coisas aqueles autores divergiam, mas ainda assim foi possível encontrar algumas opiniões unânimes entre todos eles. Podemos sintetizá-las em cinco aspectos: as experiências com a arte; as experiências com a natureza; a possibilidade de imersão em uma temporalidade distinta daquela medida pelo relógio e pelos calendários (uma temporalidade aiônica, aquela que nos ajuda a ver castelos nas nuvens); a mediação de um outro mais experiente (como aquele que aponta as estrelas e assim faz com que a criança veja nelas a figura de uma constelação); e, por fim, a experiência com a narrativa. É desta últimas que vamos 
falar a seguir: a força imaginativa que impele ao desejo de saber o que vem depois, esse desejo que foi a salvação de Scherazade e que faz a fortuna dos autores de folhetins e séries de TV. Num segundo momento, e com a ajuda de lembranças de infâncias de ficcionistas, retomaremos o papel da mediação adulta na construção de um cotidiano cultural mais rico e hospitaleiro à criação de histórias pelas crianças.

\section{a imaginação narrativa: um fazer, um brincar, uma poética}

Uma reflexão que entrelaça imaginação e narrativa de modo potente neste contexto é a do filósofo irlandês Richard Kearney. Discutindo um papel para a imaginação contemporânea, ele afirma a necessidade de incorporarmos as lições da desconstrução, ou seja, a necessidade de irmos além da concepção da imaginação como imitação ou representação. Também não é suficiente, reconhece o autor, o culto humanista a um eu transcendente, característico da concepção moderna da imaginação. Ao mesmo tempo, porém, ele vê limites no labirinto de espelhos proposto pelo paradigma pós-moderno - "o incessante jogo de uma cópia copiando outra cópia e assim por diante ad infinitum" - pois "a face do outro" nos coloca uma demanda ética. (KEARNEY, 1988, p.361). A alteridade nos exige imaginar como é que as coisas poderiam ser de um modo diferente.

Uma imaginação contemporânea que seja responsiva à dimensão ética das coisas, prossegue Kearney, precisa também ser poética, capaz de inventar e de brincar. "De fato, podemos dizer que ela precisa brincar porque é ética - para garantir que seja ética de modo liberador, de modo a que anime e amplie nossa resposta ao outro, ao invés de nos enclausurar na severidade do moralismo" (KEARNEY, 1988, p. 366). Nesse quadro, a poética aparece como "o carnaval das possibilidades", como "a disposição para nos imaginarmos na pele de outra pessoa, de vermos as coisas como se fôssemos, por um momento, outra pessoa (KEARNEY, 1988, p. 369). Estamos aí já nas vizinhanças da ficção narrativa. Mas Kearney também se preocupa muito com a relação da memória e da história com a imaginação. Para ele, uma imaginação eticamente responsável precisaria reinterpretar a memória cultural, não invocando a tradição como narrativa mestra única e totalizante, é claro, mas registrando a diversidade das narrativas formativas do passado, "como arquivos valiosos da esperança, da ação e do sofrimento humanos." (KEARNEY, 1988, p. 396).

Essa compreensão que atribui à imaginação narrativa um papel decisivo na administração das demandas éticas e estéticas, tanto individuais quanto sociais e culturais, é bastante próxima do conceito de imaginação de Paul Ricoeur (1978), também inseparável de sua preocupação com a narrativa. Ricoeur frisa que toda 
crianças inventando mundos e a si mesmas: ideias para pensar a autoria narrativa infantil

ação depende da imaginação, e que é no espaço da imaginação que experimentamos diferentes cursos de ação, e que 'brincamos"- no sentido literal do termo, ressalta - com possibilidades práticas. Para Ricoeur:

É a imaginação que proporciona o ambiente, a clareira luminosa na qual podemos comparar e contrastar motivos tão diferentes quanto desejos e demandas éticas, que por sua vez podem ir desde regras profissionais até costumes sociais ou valores estritamente pessoais. A imaginação oferece o espaço de mediação de uma 'fantasia' comum para coisas tão diversas quanto a força que empurra por trás, a atração que seduz como que pela frente, razões que justificam e estabelecem como que por baixo (RICOEUR, 1978, p.12).

Em sua obra maior, Tempo e Narrativa (1994), Ricoeur criticava a ausência de temporalidade do modelos estruturalistas de análise da narrativa, organizados com base em uma lógica sintática. Para ele, a busca de ordem, identificada na origem do impulso narrativo desde Aristóteles, tem a ver com a imaginação produtora, que teria uma dimensão temporal irredutível. Ricoeur vê no próprio tecer da intriga (o mito, a fábula), "uma autêntica inteligência narrativa", uma inteligibilidade do campo da práxis, próxima à inteligência da ação: "A poesia é, com efeito, um fazer, e um fazer sobre um fazer" (RICOEUR, 1994, p.68).

A inteligência narrativa definida por Ricoeur é, portanto, uma atividade, uma produção, já que a mimese não decalca nem presentifica um real preexistente, sendo antes uma imitação criadora. Essa criação opera o que ele chama de um "salto do imaginário" entre o ponto de partida do texto (aquilo que precede a criação narrativa) e a atividade refiguradora do leitor, espectador ou ouvinte. $\mathrm{O}$ ponto de partida para tal salto mediador é, explica Ricoeur, o lugar de uma estrutura pré-narrativa da experiência, aquilo que nos episódios do cotidiano percebemos como histórias ainda não-contadas, ou talvez até mesmo como histórias potenciais (RICOEUR, 1994, p. 115). O autor diz que com a emergência das histórias, emerge o sujeito, e que, num sentido mais amplo, "narrar, seguir, compreender histórias é só a continuação dessas histórias não-ditas" (RICOEUR, 1994, p. 116). Na mesma direção, diz Kearney: "A vida está prenhe de histórias. Ela é um enredo nascente em busca de uma parteira" (KEARNEY, 2012, p.413).

Trazendo essa reflexão para o foco nas crianças, podemos nos perguntar: o que é que pode atribuir às coisas do cotidiano das crianças essa força de semente? O que é que ajuda a haver na vida delas essa qualidade "pré-narrativa" da experiência, capaz de fazer emergir não somente histórias, mas também o próprio sujeito? Que coisas, na ação de narrar, seguir e compreender histórias, podem fazer com que o sujeito seja de algum modo parteiro de si próprio? E assim voltamos à importância de, enquanto adultos, darmos as melhores condições para que a autoria narrativa das crianças possa vicejar. 


\section{autoria narrativa infantil: um horizonte conceitual}

Antes de observarmos mais de perto a especificidade da autoria narrativa das crianças, o conceito de autoria merece algumas considerações iniciais, dados os diferentes sentidos com que ele tem sido utilizado nas ciências humanas a partir do século XX. Na filosofia e na teoria literária, uma crítica seminal da noção do autor como um indivíduo que detém a origem e é proprietário do sentido de um texto foi formulada por Roland Barthes (2004) no artigo A Morte do Autor, publicado em 1968. No bojo da virada crítica à concepção moderna de sujeito autônomo, Barthes dizia que a unidade do texto não está em sua origem, mas em seu destino, aquele lugar ocupado pelo leitor. Um ano mais tarde, Michel Foucault trouxe novas nuances para esse veredicto sobre o autor, entendendo-o também não como um indivíduo empírico, mas como uma função, sendo que esta que ainda teria lugar na análise de um texto. A função-autor seria "o resultado de uma operação complexa que constrói um certo ser racional que chamamos de autor" (FOUCAULT, 1992, p. 50). Nesse sentido, os autores são "construídos" a partir da leitura crítica dos textos, levando em conta o valor, a coerência teórica e a unidade estilística neles encontrados. $\mathrm{O}$ autor não é aí, portanto, uma origem do discurso, mas uma função variável dentro dele, e que muda ao longo da história à medida em que mudam os modos de existência e de circulação dos discursos.

Embora nossa discussão sobre autoria se preocupe mais com as forças motrizes da criação discursiva do que com a análise de discursos pré-existentes, duas ideias que Foucault apresenta nesse trabalho são muito pertinentes aqui. A primeira é o caráter histórico da noção de autoria, o que nos ampara na busca de tentar identificar como se dá a autoria infantil nas condições particulares da cultura contemporânea. Outra ideia necessária a nossa discussão é a proposta de Foucault de que a função-autor seja "uma das especificações possíveis da função sujeito" (FOUCAULT, 1992, p.70). Uma das perguntas que ele faz a partir disso é especialmente instigante: "como, segundo que condições e sob que formas, algo como um sujeito pode aparecer na ordem dos discursos?" (FOUCAULT, 1992, p.69). Se articularmos essa pergunta à proposição de Ricoeur que citamos pouco acima, de que com a emergência das histórias emerge também o sujeito, poderíamos reformular assim a questão: em que condições consegue emergir um sujeito no processo de emergência das histórias? Essa poderia ser outra forma de perguntar o que favorece a criação autoral de histórias.

Em trabalhos anteriores esboçamos um horizonte para pensar a autoria narrativa infantil, considerando que a promoção e a escuta das histórias contadas por crianças é um dos temas de pesquisa ao qual mais temos nos dedicado (GIRARDELLO, 2009; 2012; 2015). Desse horizonte faz parte uma concepção lúdica 
de autoria, que envolve um malabarismo entre criação individual, apropriação cultural e compartilhamento social. O cerne dessa ludicidade é aquilo que nos estudos do desenvolvimento narrativo na criança se chama de "o jogo do contar" (PERRONI, 1992), o diálogo em pingue-pongue em que a criança pequena, com menos de três anos de idade, diz algumas palavras e recebe do adulto um retorno, na interação curiosa que a anima a prosseguir com o relato.

O jogo do contar é, assim, uma brincadeira em parceria, um diálogo. Mesmo crianças mais velhas podem ganhar confiança para criar narrativas se tiverem a seu lado a escuta atenta de alguém. Esse exercício nos acompanha há anos, em pesquisas baseadas na escuta das histórias infantis. Um exemplo foi o projeto de construção coletiva de um livro com narrativas de crianças, desenvolvido em uma comunidade de periferia em Florianópolis em 20064. O primeiro passo do projeto foi trazer histórias da tradição oral local e da literatura universal para as crianças, narrando algumas e abrindo uma mala de livros escolhidos a dedo. A proposta era a de que as crianças os explorassem como quisessem, encharcando-se de arte e poesia, para que depois se animassem a inventar também suas histórias.

Ali conhecemos várias crianças, entre elas a menina Suelen Oliveira, na época com 8 anos de idade. É difícil esquecer da manhã de inverno em que Suelen começou a nos contar a história que queria colocar no livro. Estávamos na pequena biblioteca de um centro comunitário, e a menina, que já era miúda, quase desaparecia dentro de um casaco que provavelmente herdara de alguém bem maior. No começo, ela nos olhou desconfiada quando perguntamos o que estava pensando em contar na sua página do livro: "Não sei, prossôra".

Falamos disso e daquilo, mas a conversa não fluía muito. Queríamos saber que coisas interessavam à menina para que pudéssemos organizar alguns passeios ou trazer materiais que a ajudassem a desenvolver sua página. Perguntamos, então: "Ô Suelen, e se tu tivesses uma varinha mágica que te deixasse ganhar ou fazer qualquer coisa por um dia, o que tu ias querer?" Dessa vez parece que a chave da fantasia abriu uma porta que até então estivera fechada, e a menina respondeu, baixinho mas certeira:

- Bicicleta, prossôra.

- É? Pra ir aonde?

- Pra Lages, prossôra.

\footnotetext{
${ }^{4} \mathrm{O}$ projeto foi desenvolvido no âmbito da V Mostra de Cinema Infantil de Florianópolis, em 2006, evento coordenado por Luiza Lins, e resultou em um pequeno livro, a partir de oficinas de criação das histórias com as crianças coordenadas por nós. Maiores detalhes sobre essa experiência constam de um artigo publicado anteriormente (GIRARDELLO, 2009).
} 
Dissemos à menina que aquela era uma boa ideia para uma história. Sabíamos que muitas famílias daquela comunidade eram migrantes recentes do oeste do estado, e outras crianças já tinham incluído Lages em seus relatos, às vezes tingindo-a com as cores de um paraíso perdido.

- E como é que podia começar, Suelen?

- Uma menina. Se chamava Duda - ela falou.

- Ahã - comentei - E que é que aconteceu com ela?

- A madrinha tinha dado pra ela uma bicicleta.

- Ahã. Como é que era a bicicleta?

- Rosa. E então ela quis ir pra Lages de bicicleta, porque ela não tinha carro.

E esse ficou sendo o começo da história de Suelen, em que a protagonista subiu de fato a Serra Geral de bicicleta e chegou a Lages. Na festa de lançamento do livro, uma parente da menina comentou conosco, um pouco constrangida, o quanto a ideia da Suelen lhe parecia absurda, a de que fosse possível ir até Lages de bicicleta: “Imagina só! Tão longe!". Mas a menina Suelen não achava nada demais nisso, embora soubesse que Lages era longe da capital: "mais de cem minutos!", como explicou em sua história. Afinal, como disse Walter Benjamin, "ao inventar histórias, as crianças são cenógrafos que não se deixam censurar pelo 'sentido'" (BENJAMIN, 1984, p. 55).

Em processos como esse, que são singelos e nada incomuns em salas de aula, fica claro o caráter dialógico da construção do discurso narrativo nas crianças e da própria construção que a criança faz de si como narradora. Nem sempre esse diálogo consiste literalmente na conversa entre duas pessoas, como no exemplo acima. Pode ocorrer também no encontro com a literatura e com as artes e na atribuição de sentido às experiências vividas - as próprias e as alheias.

O diálogo pode ser entendido de modo ainda mais amplo, se recorrermos ao referencial bakhtiniano, que entende a autoria como uma prática de construção textual em diálogo com o mundo. Nela, o sujeito se responsabiliza por seus pensamentos, sentimentos e ações, como afirmam Mark Tappan e Lyn Brown (1991, p.182), acrescentando que “a autoria é possibilitada e encorajada pela reflexão de cada um sobre sua própria experiência no processo de narrar uma história" (id., p.182). Para Mikhail Bakhtin, "a atividade arquitetônica da autoria, que é a construção de um texto, corre em paralelo com a atividade da existência humana, que é a construção de um self." (CLARCK; HOLQUIST, 2008, p.90). Essa ênfase na dimensão ética da autoria converge com a noção de que, ao acompanhar histórias e ao ver ouvidas as suas próprias histórias, escolhendo o que entra no relato e o que fica fora dele, as crianças vão aprendendo a tecer narrativamente sua experiência, e assim abrem espaço para a emersão do sujeito. 
Um exemplo de cuidadosa atenção à dimensão ética da autoria narrativa das crianças, que conhecemos recentemente, são as oficinas realizadas pela Ping Chong Company em escolas públicas da periferia de Nova York, nas quais as crianças elaboram poderosas performances coletivas a partir de suas histórias de vida $^{5}$. A coordenadora pedagógica do projeto, Jesca Prudencio, explicou em entrevista a importância dessa autoria na construção de comunidades e no combate aos preconceitos, especialmente em contextos de tanta diversidade social e cultural como as escolas cheias de imigrantes nas grandes cidades: "Ao compartilhar suas histórias, você tem autoria sobre elas. Ao contar aquilo que você viveu, você tem autoria sobre aquilo, sobre aquela lembrança. Mesmo uma lembrança difícil, daquelas que fazem você chorar até hoje - aquilo faz parte de você, faz de você a pessoa forte, independente, única, que você é hoje" (GIRARDELLO, 2015, p. 19).

Não por acaso as palavras autoria e autoridade são aparentadas. Como explica Lucy Calkins, a partir de uma longa jornada formando professores para promover o letramento e a criação literária nas crianças: “Faz sentido que nós escrevamos melhor sobre assuntos nos quais somos autoridades". (CALKINS; CHIARELLA, 2006, p.3), ou seja, assuntos extraídos da própria experiência das crianças. Em um livro escrito por Calkins com Mary Chiarella, as autoras dão sugestões aos professores, no sentido de ajudarem as crianças a perceber o quanto suas vidas são preciosas:

[Diga às crianças:] “Não há dúvida de que todos vocês estão escrevendo sobre assuntos de importância gigantesca. Mas notei que o esforço de escrever bem sobre um tema gigantesco torna alguns de vocês meio inseguros. É como se vocês fossem uma criança procurando um tesouro. Vocês andam de lá pra cá com uma pá, cavando um pouco aqui, outro pouco ali, sem cavar fundo por recearem que ali não haja nenhum tesouro [...] [Mas] para escrever, vocês têm que confiar. Confiem em que as verdades da sua vida estão escondidas ali na sua escrita - qualquer um daqueles momentos pode trazer em si um carregamento precioso!" (CHIARELLA, 2006, p. 21).

A dimensão dialógica da concepção de autoria que nos ensina Bakhtin ajuda a entender que o sentido das histórias contadas oralmente não está só no enredo, nem no narrador, nem no ouvinte, mas sim na centelha de encontro que ocorre no evento único de cada performance. A metáfora da fagulha que se dá na fricção entre vozes e entre consciências aparece várias vezes na obra de Bakhtin, como nesta passagem, escrita em 1929: "A significação só se realiza no processo de compreensão ativa e responsiva. [...]. Ela é o efeito da interação entre o locutor e o receptor, produzido através do material. É como uma faísca elétrica, que só se

\footnotetext{
${ }^{5}$ Relatamos esse projeto com mais detalhes em GIRARDELLO (2012).
} 
produz quando há contato entre os polos. (BAKHTIN/VOLOCHINOV, 1990, p.132). Essa autoria dialógica é vinculada à criança na reflexão de Sonia Kramer:

Ser autor significa produzir com e para o outro [...] Somente sendo autora a criança interage com a língua; somente sendo lida e ouvida pelos outros ela se identifica, diferencia, cresce no seu aprendizado. [...] Somente sendo autora ela penetra na escrita viva e real, feita na história (KRAMER, 1993, p. 83).

As imagens da faísca elétrica em Bakhtin, assim como a do sujeito que emerge no processo de narrar descrito por Ricoeur (1994), configuram a autoria como um movimento, como algo que acontece, muito diferente portanto da ideia de que ela seja um atributo estático que alguém possua ou deixe de possuir. Para Ricoeur, contar uma história é ao mesmo tempo um modo de refletir sobre o que está sendo contado, e Tappan e Brown complementam, dizendo que nesse movimento a pessoa pode "aprender com o evento narrado [...] ponderar sobre o que aconteceu, o que ela pensou, sentiu e fez, e sobre como as coisas acabaram " (TAPPAN; BROWN, 1991, p. 182).

A concepção de autoria narrativa que estamos discutindo é também poética. Ela se baseia em uma percepção de que as crianças, como os adultos, sentem a necessidade de buscar, em seu fazer criador, a linguagem mais precisa para que a singularidade de cada história se manifeste (GIRARDELLO, 2015, p. 26). A forma com que as histórias são contadas, inseparável de seu "conteúdo, faz diferença na compreensão e no efeito estético que elas desencadeiam nos ouvintes e no próprio narrador. As escolhas formais da linguagem também são centrais na noção de autoria explicitada pelo linguista Sirio Possenti (2002) para pensar os textos criados por crianças e jovens na escola. Para ele, a autoria tem a ver com a singularidade: com um jeito de dizer, com um certo estilo, com uma tomada de posição. E tem a ver também com uma aposta a respeito do leitor, com a compreensão de que ele também sabe certas coisas sobre o mundo, ou seja, não é uma entidade neutra, um espaço vazio.

As escolhas formais da linguagem - os ritmos, tonalidades, pausas, ênfases, gestos, o que entra e o que fica de fora, o como, enfim, do narrar - fazem parte da responsabilidade pela história que cada criança decide contar. Como explicou a coordenadora pedagógica do projeto da Ping Chong Company: "não se trata apenas de 'vamos compartilhar histórias' e sim de 'vamos escrever e encenar as histórias o melhor que a gente puder'. Assim as crianças desenvolvem aspectos estéticos de linguagem cênica, e também aprendem sobre elas mesmas" (GIRARDELLO, 2012, p.25). O envolvimento de todos na produção imaginária é sensível aos ritmos e à musicalidade da vocalização, aos recursos poéticos da palavra, e a toda uma dimensão coreográfica que, por mais simples que seja, 
crianças inventando mundos e a si mesmas: ideias para pensar a autoria narrativa infantil

assinala a presença do corpo na linguagem. Aquela presença na qual, para Walter Benjamin, além da voz também o olho e a mão coordenam-se com a alma:

Pois a narração, em seu aspecto sensível, não é de modo algum o produto exclusivo da voz. Na verdadeira narração, a mão intervém decisivamente, com seus gestos, aprendidos na experiência do trabalho, que sustenta, de mil maneiras o que é dito. A antiga coordenação da alma, do olho e da mão [...] é típica do artesão, e é ela que encontramos sempre, onde quer que a arte de narrar seja praticada. (BENJAMIN, 2012, p. 239).

Benjamin diz aí que a narração é tanto uma arte quanto um artesanato: ele não distingue uma coisa da outra. Em ambas salta a presença do corpo. Esse corpo que se manifesta nos ondulares da voz e nos movimentos da mão, que tanto na fala quando na escrita experimentam: entrecruzam e tecem, colhem e escolhem, acolhem e excluem, deletam e trocam, olham de novo para ver como fica, dizem de novo para ver como soa.

Quando aqui falamos de autoria narrativa, estamos pensando no impulso imaginário e afetivo para a criação de histórias, independente de essa criação ocorrer na oralidade ou na escrita. No caso das crianças, tal distinção é ainda menos importante para o que estamos buscando entender. Primeiro, porque o desejo de contar histórias surge muito antes de a maioria das crianças terem pleno domínio da escrita, e mesmo da leitura. Entre os muitos autores que se dedicaram a estudar as narrativas das crianças pequenas, já citamos Maria Cecília Perroni (1992), que identificou o "jogo-de-contar", entre crianças de menos de três anos de idade. E podemos lembrar também o lindo trabalho de Vivian Gussin Paley, que, a partir de uma vida inteira como professora de educação infantil nas escolaslaboratório da Universidade de Chicago, descreveu em seus muitos livros os processos de criação coletiva de histórias nos grupos de crianças pequenas. Ela observa que a brincadeira de faz-de-conta na primeira infância é um tipo de criação de histórias: a criança que brinca está sempre inventando enredos, ou tentando participar dos enredos inventados pelos amigos, até como uma forma de apreender o mundo que a cerca. O faz-de-conta, assim, é uma história em forma de ação (PALEY, 1991).

A força da corporeidade na experiência das crianças é outra razão para não separar a oralidade e a escrita na investigação daquilo que mobiliza a autoria narrativa das crianças. Isto porque tanto na palavra falada como na escrita está presente a dimensão física, ainda que na escola se costume dar primazia à sua dimensão racional. A afinidade entre a prática da escrita e as demais práticas do movimento humano é enfatizada por Natalie Goldberg, para quem a primeira regra da prática de escrever é "manter a mão em movimento" (GOLDBERG, 1990). E a escritora Lídia Bojunga conta assim suas lembranças do ato físico de escrever, quando era 
menina: "E ficar desenhando e apagando letra, escrevendo e reescrevendo palavra, era bom. Feito ir lá pro quintal mexer na terra. Feito depois encher a banheira e ficar lá dentro dela, eu e mais o barco que eu vivia fazendo de papel" (NUNES, 1988, p.35). É claro que existem especificidades na oralidade e na escrita, mas optamos aqui por manter o foco no impulso comum que leva à criação de histórias, tanto na performance oral como na prática do escrever.

Entre os mais poderosos adubos da autoria infantil está a atenção ao que a criança fala, performa, desenha ou escreve. Como diz Luciana Hartmann, a partir de seus estudos da performance como "arte verbal", proposta pelo antropólogo Richard Bauman: "O que é preciso para que uma criança conte uma história? Penso que o fundamental nessa resposta é: alguém que a escute - o que inclui ouvintes tão diversos quanto: outras crianças, adultos, animais de estimação ou mesmo seus bonecos preferidos" (HARTMANN, 2015, p.48).

Escutar a criança é não ter pressa, nem querer que ela "diga logo" alguma coisa. Assim, perguntar "e daí?", no jogo dialógico do contar, não significa forçá-la a chegar a um sentido como quem espreme uma laranja para obter-lhe o suco. Escutar a criança é dar-lhe tempo para divagar, devanear, buscar a palavra certa, tatear suas lembranças, brincar com as imagens mentais, que são matéria-prima das histórias, como a argila na mão do oleiro de que fala Benjamin (2012) ao valorizar o caráter artesanal da narração oral.

Para que a narrativa da criança brote de uma terra funda, é preciso tempo, pois "as horas param para que dentro da história cada um que conta ou escuta possa brincar", como diz lindamente Regina Machado (2002, p.49). Um sintoma do quanto nossa cultura é ainda adultocêntrica, apesar de toda a crítica que temos feito a isso desde os estudos da infância, é a facilidade com que se interrompe o que as crianças estão dizendo, dando a elas apenas uma vaga atenção, ou fazendo de conta que as estamos ouvindo, quando de fato nosso olhar passa através delas enquanto pensamos em outras coisas. Uma pedagogia poética, como propõe Georges Jean, precisaria ser alimentada por contos e poemas, e aberta a um tempo mais lento, onde escutar fosse tão importante quanto falar, e um direito garantido não só aos adultos mas também às crianças:

A escola, em muitos casos, proíbe a fulguração, assim como proíbe a
lentidão e a paciência; a criança aprende assim a ajustar o ritmo de sua
vida, como o de sua linguagem, conforme itinerários seguros e bem
delimitados que excluem tanto a vertigem como os giros incertos dos
labirintos (JEAN, 1990, p.16).

Outras vertigens e labirintos batem hoje à porta da escola, trazidos pela cultura digital participativa que marca a contemporaneidade, e que é o ambiente de novos desafios para pensar a autoria narrativa das crianças. As redes eletrônicas de 
crianças inventando mundos e a si mesmas: ideias para pensar a autoria narrativa infantil

comunicação pulverizam a autoria individual, favorecendo modelos híbridos, colaborativos e dialógicos de autoria, em " uma nova configuração que não corresponde à dissolução completa do autor, mas também não à autoria individualizada" (MARTINS, 2014, p.52).

Brilha aí o potencial de novos gêneros narrativos para inspirar a autoria das crianças, inclusive na escola. Um exemplo é o das histórias criadas por crianças e jovens e compartilhadas on-line a partir dos universos ficcionais de livros e filmes (fanfiction). Essa intensa produção narrativa, baseada em técnicas de remixagem de signos e conteúdos, é considerada um caso paradigmático de novo letramento, afinado com o ethos participativo favorecido pelas tecnologias, segundo Lankshear e Knobel (2006). Os autores desenvolveram toda uma tipologia de narrativas fanfic, incluindo: a invenção de novos episódios a partir dos cenários, personagens e tipos de enredos de um texto midiático original; a transposição de personagens de um universo ficcional para outro; o cruzamento entre personagens de universos ficcionais diferentes; a criação de histórias envolvendo personagens secundários de um texto original; e narrativas em que os autores inserem a si próprios como personagens em um universo ficcional pré-existente. Os pesquisadores exaltam a vitalidade desse tipo de criação narrativa entre crianças e jovens do mundo todo, "que dedicam muito tempo e energia a desenvolver-se em desafiadoras habilidades de linguagem e artes de produção midiática, [...]criando roteiros, editando, animando, desenhando e escrevendo", em práticas que merecem ser levadas a sério enquanto letramento (LANKSHEAR; KNOBEL, 2006, p.136).

Os fenômenos contemporâneos de recriação coletiva de universos ficcionais préexistentes são novos por seu caráter compartilhado e plural. Mas eles se inserem em uma longa tradição, aquela em que as crianças mergulham imaginariamente nos mundos ficcionais circulantes na cultura de seu cotidiano - na oralidade, na literatura, no cinema, no teatro - e a partir desse mergulho intenso começam a criar também suas histórias. Dizia Monteiro Lobato que "para as crianças um livro é todo um mundo" e que seu sonho era fazer livros onde as crianças pudessem morar: "Não ler e jogar fora; sim, morar, como morei no Robinson [Crusoé] e n'Os Filhos do Capitão Grant", livros que tinha lido na infância (LOBATO, 1951, p.293). Inventar histórias pode ser para as crianças, então, uma forma de continuar vivendo nos lugares e entre as personagens com quem viveram o tipo particular de felicidade e sentido que a ficção narrativa nos oferece.

Esboçamos até aqui um horizonte de compreensão para a autoria narrativa infantil, baseado no laço amplo entre imaginação e narrativa. A seguir, retomaremos um fio que ficou aguardando lá atrás: o da importância da mediação adulta nesse 
processo, pelo oferecimento de universos narrativos capazes de enriquecer a imaginação infantil. Isso tem diretamente a ver com a responsabilidade pelo mundo e pelas crianças à qual, seguindo os mestres que nos inspiram, nem queremos nem poderemos fugir.

\section{primeiras histórias: lembranças de grandes imaginadores}

O convite aqui é para reentrarmos no território por outra porta, a das memórias de infância. Vamos seguir pela mão de alguns escritores de ficção (esses imaginadores profissionais) que lembram como a narrativa entrou em sua infância e fez brotar neles o desejo ou a necessidade de contar histórias. Estaremos assim procurando acrescentar ao exame do tema da autoria narrativa infantil aquilo que alguns ficcionistas conseguem relatar sobre os modos como o impulso narrativo emergiu neles próprios quando eram crianças. O que o cotidiano cultural dessas crianças disponibilizava a elas para que se deixassem tocar pelo condão da poesia e da aventura, animando-as a inventar o que ainda não existia e criando assim também a si próprias?

Começamos por lembrar a força das histórias orais na vida das crianças, a partir das palavras de João Guimarães Rosa, em entrevista que deu em 1965:

Desde pequenos, estamos constantemente escutando as narrativas multicoloridas dos velhos, os contos e lendas, e também nos criamos em um mundo que às vezes pode se assemelhar a uma lenda cruel. Deste modo a gente se habitua, e narrar estórias por nossas veias e penetra em nosso corpo, em nossa alma, porque o sertão é a alma dos nossos homens. Assim não é de se estranhar que a gente comece desde muito jovem. Deus meu! No sertão o que pode uma pessoa fazer do seu tempo livre a não ser narrar estórias? A única diferença é que eu, em vez de contá-las, escrevia. (LORENZ, 1991, apud RODRIGUES, 2012).

Além da escuta das histórias dos mais velhos, que lhe penetraram como que nas veias, Guimarães Rosa fala aí, também ele, do valor do tempo largo e lento, esse "tempo livre" vasto como o sertão, em que contar histórias parece quase uma fatalidade: o que mais se poderia fazer, a não ser isso?

Outro escritor que lembra das histórias ouvidas como um impulso para sua própria criação narrativa é o inglês Philip Pullman, autor do clássico de fantasia "A Bússola Dourada". No seu caso, as histórias não vinham da tradição oral, e sim da imaginação do avô, que as inventava em lúdico improviso, passeando com o neto: "Quando era um menininho, eu saia a caminhar com meu avô, e ele ia dizendo: Agora, rapazinho, vamos atravessar um riacho. Esse riacho se chama Água que Ri. Vou te contar por que ele se chama assim." (MARCUS, 2006, p.170).

A leitura literária é com certeza um dos mais potentes motores da autoria narrativa na infância dos escritores. Vejamos como Lygia Bojunga relata esse efeito 
crianças inventando mundos e a si mesmas: ideias para pensar a autoria narrativa infantil

da literatura em suas lembranças do tempo de menina, quando foi tocada pela força da obra de Monteiro Lobato: "[O livro] Reinações de Narizinho tinha-me dado um prazer tão intenso, que era pra ele que eu voltava sempre ao longo de minha infância. Esse livro sacudiu a minha imaginação. E ela tinha acordado. Agora...ela queria imaginar" (NUNES, 1990, p.13). Bojunga conta que essa imaginação que tinha sido acordada pela literatura não se limitava aos confins da leitura, mas se manifestava por todo lado:

De repente, já não me bastava contar junto a música que tocava no rádio, só repetindo as palavras e mais nada. Eu me lembro de uma música que eu cantava sempre, e que falava numa tal Maria abrindo a janela numa manhã de sol e laralalá não sei o quê, mas que, agora, eu cantava querendo imaginar a janela: era verde? tinha veneziana? E a Maria, como é que era? ela era gorda, ela era magra, ela tinha uma franja assim feito eu?" (NUNES, 1990, p.13).

É bonito o modo como ela descreve a emoção criadora que sentia quando criança, essa vontade de enxergar coisas com os "olhos de dentro" e de fazer acontecerem coisas inéditas no mundo, só por meio de sua ação imaginativa.

A literatura como impulso para a criação narrativa na infância aparece também na voz vigorosa da escritora nigeriana Chimamanda Ngozi Adichie, em uma palestra na qual ela faz uma crítica ao colonialismo cultural, advertindo para "os perigos da história única":

Fui uma leitora precoce. E o que eu lia eram livros infantis ingleses e americanos. Fui também uma escritora precoce. E quando comecei a escrever, por volta dos sete anos de idade, histórias a lápis com ilustrações feitas com lápis-cera que minha pobre mãe era obrigada a ler, e eu escrevia exatamente o tipo de histórias que estava lendo. Todos os meus personagens eram brancos de olhos azuis. Eles brincavam na neve. Eles comiam maçãs. E eles falavam muito sobre o tempo que fazia lá fora: que bom que finalmente o sol tinha aparecido. Isso tudo, apesar do fato de que eu vivia na Nigéria. Nós não tínhamos neve. Comíamos mangas. E nunca conversávamos sobre o tempo, porque não era preciso. [...] Eu amava aqueles livros americanos e ingleses que lia. Eles atiçaram a minha imaginação. Eles abriram mundos para mim. Mas sua consequência nãointencional foi eu não saber que pessoas como eu podiam existir na literatura. Assim, o que a descoberta dos escritores africanos fez por mim [mais tarde] foi isto: eles me salvaram de ter uma única história sobre o que os livros eram" (ADICHIE, 2009).

Abramos um parêntesis a partir da citação acima: poucos depoimentos seriam uma defesa mais contundente da importância da variedade na oferta de textos artístico-culturais para as crianças. Para que se constituam como sujeitos mais cuidadosos, amorosos e sensíveis aos outros, elas precisam ter acesso a diferentes gêneros, estilos, formatos, linguagens, estéticas, a diferentes vozes, vindas de outros tempos e de lugares diversos do mundo. A filósofa Maxine Greene complementa essa defesa do papel da imaginação na construção de mundos comuns: 
Queremos que nossas salas-de-aula sejam reflexivas e justas; queremos que nelas pulse uma pluralidade de concepções sobre o que é ser humano e estar plenamente vivo. Queremos que elas estejam cheias dos sons de crianças e jovens articulados, em diálogos contínuos, abrindo-se uns aos outros, abrindo-se ao mundo (GREENE, 1994, p.25).

Fechado o parêntesis, retomemos as lembranças dos ficcionistas sobre suas primeiras histórias. Para outras crianças, a inspiração à autoria narrativa veio do mergulho nas histórias que viam na tela do cinema, como conta Jean-Paul Sartre em suas memórias de infância:

Como eram felizes aqueles cowboys, aqueles mosqueteiros, aqueles policiais; o seu futuro estava ali, naquela música premonitória, e governava o presente [...]. Eram esperados: pela moça em perigo, pelo general, pelo traidor emboscado na floresta, pelo amigo amarrado junto de um barril de pólvora e que observava tristemente a chama correr ao longo do rastilho. A corrida desta chama, a luta desesperada da virgem contra o raptor, a galopada do herói pela estepe, o entrecruzamento de todas essas imagens, de todas essas velocidades. [...]. Eu me sentia satisfeito, encontrara o mundo em que desejava viver, tocava no absoluto (SARTRE, 1967, p.80).

Quanto as luzes se acendiam e o menino Jean-Paul saía à rua, sentia-se pequeno e sozinho, e assim decidiu escrever histórias a partir dos filmes que tinha visto, como que para continuar dentro daquele mundo absoluto em que desejava viver:

Quando minha mãe perguntava [...]: "Meu bem, o que é que você está fazendo?", acontecia-me por vezes romper o voto de silêncio e responder-lhe: "Faço cinema". Com efeito, eu tentava arrancar as imagens de minha cabeça e realizá-las fora de mim, entre verdadeiros móveis e verdadeiras paredes, resplendentes e visíveis tanto quanto os que jorravam sobre as telas. (SARTRE, 1967, p.89)

E o primeiro "romance" do autor, escrito aos sete anos, foi diretamente inspirado por uma história em quadrinhos. Nas palavras de Sartre, chegou até mesmo a ser um plágio:

Pedi que me dessem um caderno, um vidro de tinta violeta, inscrevi na capa; "Caderno de romances". O primeiro que levei a cabo, intitulei: "Por uma borboleta". Um sábio, sua filha e um jovem explorador atlético subiam o curso do Amazonas à caça de uma preciosa borboleta. $\mathrm{O}$ argumento, as personagens, o detalhe das aventuras, o próprio título, eu tomara a uma história em quadrinhos que aparecera no trimestre precedente. Esse plágio deliberado me livrava de minhas últimas inquietações: tudo era forçosamente verdadeiro, visto que eu não inventava nada. [...] Considerava-me eu um copista? Não. Mas sim autor original: eu retocava, remoçava; por exemplo, adotara o cuidado de trocar os nomes das personagens. Essas ligeiras alterações me autorizavam a confundir a memória e a imaginação. Novas e totalmente escritas, certas frases se reformavam em minha cabeça com a implacável segurança que a gente atribui à inspiração. Eu as transcrevia, elas assumiam a meus olhos a densidade das coisas. Se o autor inspirado, como se crê comumente, é outro que não ele mesmo no íntimo de si próprio, conheci a inspiração entre os sete e os oito anos (SARTRE, 1967, p.89/90). 
Esse trecho de Sartre chama atenção para a seriedade com que muitas crianças encaram sua atividade de criação narrativa. Quem convive com crianças e qualquer um que já tenha sido criança! - sabe o quanto é comum entre tantas delas o investimento de horas e horas na confecção de livros artesanais, de roteiros teatrais encenados com os amigos para uma plateia de vizinhos e parentes, assim como a montagem e o compartilhamento de vídeos de ficção, hoje tão facilitados pela tecnologia. Outro aspecto a destacar nas lembranças de Sartre é a tensão entre plágio e originalidade na autoria, que o dialogismo de Bakhtin ajudaria bastante a entender. O menino não se considerava "um copista"; afinal, tinha mudado muitas coisas nas histórias em quadrinhos que o tinham mobilizado, e nessas alterações o texto original assumia aos olhos do menino "a densidade das coisas". Havia alguma qualidade na história em quadrinhos que o havia tocado, fazendo com que desejasse "morar ali dentro" um pouco mais, agora com a autoridade de quem se converte em dono do lugar, porque também o ajudou a construir e a reconstruir. Fica para nós o registro da importância de que se ofereça às crianças produtos culturais com esta certa "qualidade", esta potência de aderir-se à memória e de atrair a imaginação da criança, que Sartre aqui chama de inspiração.

As histórias em quadrinho foram também a maior "escola de fabulação" para outro romancista, Italo Calvino, que declara ter sido era apaixonado por elas entre os 3 e os 6 anos de idade. Mesmo depois que aprendeu a ler, ele não dava muita importância ao texto, preferindo "fantasiar em cima das figuras, imaginando a continuação" (CALVINO, 1990, p. 109). Aos sete ou oito anos, Philip Pullman também adorava as HQ - Superman, Batman, Capitão Marvel além de histórias de detetive, terror e contos de fadas, e diz que isso o animou a contar histórias para os amigos: "eu recontava para eles as histórias que tinha lido, para fazê-los tremer de medo!"(MARCUS, 2006, p.169). Nos dois casos chama atenção o prazer que as crianças podem sentir ao inventar histórias, a dimensão lúdico-poética desse fazer.

Outros escritores contam que foi o cinema sua primeira inspiração para criar histórias na infância. Salman Rushdie diz que sua grande influência literária - aquilo que fez dele um escritor - foi o filme "O mágico de Oz", que assistiu aos 10 anos (RUSHDIE, 1992). Isso porque, sugere ele, o filme possui uma intensa "verdade imaginativa", uma qualidade que torna possível "o salto imaginativo para dentro da Terra das Histórias, o voo nas alturas rumo a Oz" (RUSHDIE, 2002) . E quando um repórter perguntou a Gore Vidal quando é que ele havia escrito seu primeiro romance, o escritor respondeu: "Mais ou menos aos sete [anos]. Era um romance inspirado de perto num filme de mistério que eu tinha visto" (MAFFEI, 1988, p.262). 
Todas essas crianças se deixaram tocar pelo laço primordial e prazeroso amarrando imaginação e narrativa e pelo mútuo estímulo entre narrativa verbal e imagética, fenômenos que parecem ainda mais cruciais nos processos subjetivos e culturais das crianças de hoje, dada a centralidade que neles possui a imagem midiática.

\section{notas finais: uma sensação de "liberdade rondando"}

Depois de acompanhar tantos vários meandros da autoria narrativa infantil, parece-nos que um arremate final, ainda que provisório, só poderia ser feito pelas palavras de alguém muito em sintonia com sua própria experiência de criança. Trazemos então, mais uma vez, a voz de Lygia Bojunga, para falar de seu primeiro encontro, na infância, com a prática da criação de histórias:

O luxo de corrigir e reescrever, somado à sensação de liberdade me rondando, me roçando, me envolvendo, fez uma impressão tão forte dentro de mim, que eu saí desse primeiro encontro pressentindo que fazer literatura ia ser pra mim uma imensa aventura interior. E desde esse dia eu confundo as palavras livro e livre: me acontece muito querer dizer uma e sair a outra" (NUNES, 1988, p.55).

A "sensação de liberdade rondando" fica como nota final desta reflexão sobre a autoria narrativa das crianças. Nos perguntávamos, no início, pelas condições que poderiam favorecer a emergência do sujeito na invenção de histórias das crianças. Por se tratar de uma daquelas perguntas impossíveis de responder de modo definitivo, deixamos aqui os apontamentos do percurso caminhado, esperando estar contribuindo para a continuidade dos estudos sobre o tema. A autoria narrativa infantil requer a singularidade de um tempo, de um espaço, de uma escuta, e os materiais inspiradores para uma criação de histórias que possa significar para as crianças a liberdade e a experiência de uma grande aventura interior. Como diz Maxine Greene, as crianças que na escola tiverem tempo e acolhimento para contar suas histórias, poderão olhar, junto com seus professores, para "possibilidades ainda não conhecidas, explorando o que significa transformar" (1994, p.24). Assim, a aventura de criação subjetiva que ocorre quando a criança inventa mundos narrativos pode não se separar da aventura de transformar o mundo social, e talvez seja até mesmo indispensável a ela. 
crianças inventando mundos e a si mesmas: ideias para pensar a autoria narrativa infantil

\section{referências}

ADICHIE, Chimamanda Ngozi. The danger of a single story. Disponível em:.

$<<$ https://www.ted.com/talks/chimamanda_adichie_the_danger_of_a_single_story?lan guage=pt-br $>>$ Acesso em 21 de jan. de 2017.

ARENDT, Hannah. Entre o Passado e o Futuro. Trad. Mauro W. B. Almeida. São Paulo: Perspectiva, 2003.

AUSTER, Paul. The Invention of Solitude: a memoir. New York: Penguin, 1982.

BARTHES, Roland. O rumor da língua. Trad. Mario Laranjeira. São Paulo: Martins Fontes, 2004.

BENJAMIN, Walter. Reflexões: a criança, o brinquedo, a educação. Trad. Marcos Mazzari. São Paulo: Summus, 1984.

BENJAMIN, Walter. O Narrador: considerações sobre a obra de Nikolai Leskov. In: BENJAMIN, Walter. Magia e Técnica, Arte e Política: ensaios sobre literatura e história da cultura. (Vol.1) Trad. Sérgio P. Rouanet. São Paulo: Brasiliense, 2012.

CALVINO, Italo. Seis propostas para o próximo milênio. São Paulo: Companhia das Letras, 1990.

CAMPOS, Karin Cozer. Nossas vidas contam histórias: crianças narradoras. (Tese de

Doutorado). Programa de Pós-Graduação em Educação, Universidade Federal de Santa Catarina. Florianópolis, 2016.

FERNANDES, Adriana Hoffmann. Infância e Cultura: o que narram as crianças na contemporaneidade? (Tese de Doutorado). Programa de Pós-Graduação em Educação, Universidade dos Estado do Rio de Raneiro, 2009.

FOUCAULT, Michel. O que é um autor? Trad. A.F. Cascais e E Cordeiro. Lisboa: VegaPassagens, 1992.

GIRARDELLO, Gilka. A produção narrativa oral das crianças: estratégias de apoio. In: VASQUES, Carla; SCHLICKMANN, Maria S.; CAMPOS, Rosânia (Org.). Educação e Infância: múltiplos olhares, outras leituras. Ijuí, RS: Ed. Unijuí, 2009.

GIRARDELLO, Gilka. Autoria narrativa infantil, mídia-educação e novos letramentos: um percurso de pesquisa. Educação On-Line (PUCRJ), v. 11, p. 1-15, 2012.

GIRARDELLO, Gilka. Horizontes da Autoria Infantil: as narrativas das crianças na educação e na cultura. Boitatá, (Revista do GT de Literatura Oral e Popular da ANPOLL). Londrina, n.20, p. 14-27, jul-dez 2015.

GREENE, Maxine. Multiculturalism, community and the arts. In: DYSON, Anne Haas; GENISHI, Celia. The need for story. New York: Teachers College Press, 1994.

GREENE, Maxine. Releasing the Imagination: essays on education, the arts and social change. San Francisco: Jossey-Bass, 1995. 
HARTMANN, Luciana. Equilibristas, viajantes, princesas e poetas: performances orais e escritas de crianças narradoras. Boitatá (Revista do GT de Literatura Oral e Popular da ANPOLL). Londrina, n.20, p. 48-67, jul-dez, 2015.

JEAN, Georges. Los Senderos de la Imaginación Infantil: los cuentos, los poemas, la realidad. Mexico, D.F.: Fondo de Cultura Económica, 1990.

KEARNEY, Richard. The Wake of Imagination: Toward a postmodern culture. Univ. of Minnesota Press, 1988.

KRAMER, Sonia. Por entre as Pedras: arma e sonho na escola. SP, Ática, 1993.

LANKSHEAR, Colin; KNOBEL, Michele. New Literacies: everyday practices and classroom learning. Maidenhead; New York:McGraw Hill/Open University, 2006.

LOBATO, Monteiro. A Barca de Gleyre. Vol.2. São Paulo: Brasiliense, 1951.

MACHADO, Regina. No tempo em que não havia tempo. In GIRARDELLO, G. (org.):

Baús e Chaves da Narração de Histórias. Florianópolis: SESC/SC, 2004.

MAFFEI, Marcos (org.). Os Escritores: as históricas entrevistas da Paris Review. São Paulo: Companhia das Letras, 1988.

MARCUS, Leonard S. (org.). The wand in the word: conversations with writers of fantasy. Cambridge, Mass.: Candlewick Press, 2006.

MARTINS, Beatriz Cintra. Autoria em Rede: os novos processos autorais através das redes eletrônicas. Rio de janeiro: Mauad, 2014.

NUNES, Lygia Bojunga. Livro: um encontro com Lygia Bojunga Nunes. Rio de Janeiro: AGIR, 1988.

PALEY, Vivian Gussey. The boy who would be a helicopter: the uses of storytelling in the classroom. Cambridge: Harvard University Press, 1991.

PALEY, Vivian Gussey. A child's work: the importance of fantasy play. Chicago: University of Chicago Press, 2005.

PERRONI, Maria Cecília. Desenvolvimento do discurso narrativo. São Paulo: Martins Fontes, 1992.

POSSENTI, Sírio. Indícios de Autoria. Revista Perspectiva /UFSC, v. 20, n. 01, p., 105-124, jan./jun. 2002.

RICOEUR, Paul. Imagination in Discourse and in Action. The Human Being in Action, Analecta Husserliana vol.VII, 1978, D. Reidel Publishing Company, Dordrecht: Holland; Boston e Londres.

RICOEUR, Paul. Tempo e Narrativa (tomo I). Trad. C.M. Cezar. Campinas: Papirus, 1994. RICOEUR, Paul. Tempo e Narrativa (tomo II). Trad. M. Appenzeller. Campinas: Papirus, 1995.

RODRIGUES, Camila. A voz das palavras mágicas de Joãozito Guimarães Rosa. Anais do III Congresso Internacional de Leitura e Literatura Infantil e Juvenil. Porto Alegre: PUCRS, 2012. Disponível: < http://ebooks.pucrs.br/edipucrs/anais/IIICILLIJ/Index.html> 
crianças inventando mundos e a si mesmas: ideias para pensar a autoria narrativa infantil

RUSHDIE, Salman. The Wizard of Oz. Londres: British Film Institute, 1992.

RUSHDIE, Salman. Step Across this Line. The New York Times, 13/10/2002.

SARTRE, Jean-Paul. As Palavras. Trad. J. Guinsburg. São Paulo: Difusão Europeia do

Livro. 3. ed., 1967.

recebido em: 28.09.2017

aceito em: 23.11.2017 